\title{
Current Manifestations of the Ethnic Identity of Transylvanian Saxons
}

\section{TOMÁŠ DRS}

Institute of Ethnology,

Charles University in Prague

tomas.drs@seznam.cz

\begin{abstract}
The study 'Current Manifestations of the Ethnic Identity of Transylvanian Saxons' presents this ethnic minority in Romania. Based on the theoretical concepts of T. H. Eriksen, it deals with the issues of the ethnic identity and its contemporary manifestations in the culture of Transylvanian Saxons. Information gathered during the qualitative field research make it possible to capture changes in the manifestations of the ethnic identity and the relationship between the minority and the majority culture. As a result of modernization processes and large-scale emigration, there has been a change of the group's mentality, with traditional behaviour patterns and models of social coexistence disintegrating. The need has arisen to revise the ethnic identity of the community. The observed aspects of the ethnic identity include ethnicity and Saxon self-concept, Saxon dialect, Saxon Evangelical Church, festivities, minority education and interethnic relations. Attention is also paid to the opinions of Saxon politicians and intellectuals of the current situation of the society and its future direction.
\end{abstract}

KEY WORDS: ethnic minority, Transylvanian Saxons, ethnic identity, identity strategies, ethnology 
The present study focuses on the current state of the ethnic minority of Transylvanian Saxons. ${ }^{1}$ It pays particular attention to the transformation of the self-concept and identity symbols of this group under the new conditions of its postdiasporical existence in the transnational space. During my field research in Transylvania I was puzzled by the fact that different people made different statements as to what was, is and will be Saxon. Respondents differed in their evaluations of the current situation of the Transylvanian Saxons. It was impossible to find a unifying universal outlook on the classification of the Saxon culture and its identity strategy. This confirmed the thesis of a fluid nature of identities, which are embedded in the fabric of social networks and relationships. During the field research the observed social categories proved to be contextually negotiated and uneven. ${ }^{2}$

1 Transylvanian Saxons are a German-speaking ethnic minority settled in the area of Transylvania, Romania. They represent the oldest still existing German language group of settlers in Eastern Europe. Areas populated by Transylvanian Saxons never had strong ties to the German Reich territory. Since the Middle Ages they belonged to the Hungarian Kingdom and the Habsburg monarchy while in modern times they have been part of the Romanian state. About 300,000 Saxons lived in Transylvania before World War II. Currently, there are nearly 15,000 of them living there. Since the 1970's Transylvanian Saxons have been leaving to live and work abroad. Shortly after 1989, most of them left for the Federal Republic of Germany and other Western countries. The massive outflow of Transylvanian Saxons became commonly known as Auswanderungsschock. Nowadays, large and organized groups of Saxons are living in Germany, Austria, USA and Canada. Only a small part of them have returned. For basic information about the history, culture and present of the Transylvanian Saxon population see eg.Wikipedia.de entry Siebenbürger Sachsen. Available at http://de.wikipedia.org/wiki/Siebenb\%C3\%BCrger_Sachsen. Also, GÜNDISCH, K. (1998): Siebenbürgen und die Siebenbürger Sachsen. München: LangenMüller. For Czech sources see ŠATAVA, L. (1994): Národnostní menšiny v Evropě. Praha: Ivo Železný, pp. 253-254, or a brief historical overview by WEITHMANN M. (1996): Balkán. 2000 let mezi Východem a Západem. Praha: Vyšehrad. For a study focused on the issue of migration see DRS, T. (2015): Migrace sedmihradských Sasů. In. Bittnerová, D. - Moravcová, M. (eds): Etnické komunity - Balkánské cesty. Jihovýchodní Evropa v interdisciplinární perspektivě. Jihovýchodní Evropa v prožité minulosti a naděj ích budoucnosti. Praha: Faculty of Humanities.

2 The text is based on a field research conducted in selected rural and urban areas in 20112014. These include the villages of Biertan, Mălâncrav, Richis, Nou Sasesc, Copsa Mare or Copsa Mica situated near the town of Mediaş in the core area of the historic Saxon settlement called Altland. Urban locations researched include Mediaş and Sibiu. In addition to studying literature and documentary sources, the research draws heavily upon structured and open interviews. The responses capture the self-concept of Transylvanian Saxons, manifestations of their ethnic identity, retrospective perception and evaluation of critical events that determined the present form and state of the Transylvanian Saxons' minority in Romania and in exile. I have interviewed 35 respondents on the issue of their ethnic identity. Most of Transylvanian Saxons were contacted in the village Biertan, where I spent most of the time and assembled a number of contacts. Those were both Saxons permanently living in Romania and those who had returned home for various reasons and for various periods of time. The respondents were contacted mainly based on recommendations. Some were interviewed repeatedly. In remote villages like Mălâncrav or Nou Sasesc, where I was unfamiliar with the local environment, I was forced to 
Pluralism of ideas and formulations highlights the ethnic identity as a socially constructed and narratively shaped category that continually changes over time and exists within the relation between the subject and the culture. It has situational and multi-layered character. In connection with the constitution of identities in discursive frameworks in interaction with varying structures of power and knowledge one can refer to concepts of Michel Foucault. When considering the relationship of the individual and social structures, where an actor is under the influence of their position within the structure while interactively forming the outside world, Pierre Bourdieu presents his habitat theory, according to which the dispositional understanding of identity is conceived as an unconscious part of everyday negotiations. ${ }^{3}$

In examining the nature and the current situation of Transylvanian Saxons one needs to observe the signs and symptoms of their ethnic identity. The interest in the phenomenon of ethnicity is related to the concepts of globalization, identity and modernity. Owing to its knowledge of social life traced from everyday interactions, ethnologic fieldwork illustrates the manifestations of ethnic identity with valuable information. It is the very everyday life where ethnicity is born. The notion of an ethnic group includes the idea of contact and relationship. It assumes that all its members live in an interconnected world. Ethnic communities are aware of the existence of other groups and their members. They seek to define themselves against other communities. Ethnicity is an aspect of a relationship, not of a group's feature. The observed group is urged to set out the society's boundaries, emphasizing the contrasts and the differences between the concepts of Us and Them. There are a number of definitions of ethnicity. One possible approach is offered by the Norwegian anthropologist T.H. Eriksen:

"Ethnicity is an aspect of social relationship between individuals who consider themselves to be fundamentally different from members of other groups whose existence they realize

\begin{abstract}
carry out random sampling relying on the good will and openness of the Saxons. Only in a few cases was I refused and referred to other neighbours, mainly in a fairly closed Saxon community in Mălâncrav. Questionnaire surveys were mostly used during the first research in 2011.Overall, I accumulated 45 completed questionnaires. I distributed the questionnaires personally and went through the items with the respondents. A more detailed analysis of problems and motivations were subsequently conducted through interviews. Attempts made by Saxons themselves to distribute the questionnaires failed to prove successful. Interesting results and evaluation possibilities were mainly generated by the scaling method which I used especially for questions as to the ethnic identity of Transylvanian Saxons. I also used questionnaires to contact Romanians and to determine the inter-ethnic relations and the issues of majority-minority coexistence.

3 On discourse: FOUCAULT, M. (1994): Diskurs, autor, genealogie. Praha: Svoboda. On habitus: BOURDIEU, P. (1998): Teorie jednání. Praha: Karolinum.
\end{abstract}


and with which they come into contact. Therefore, it can also be defined as a social identity based on a contrast to specific others, defined by metaphorical or fictive kinship. Social relationship includes an ethnic element as long as the cultural differences regularly affect the mutual contact of members of these groups ". ${ }^{4}$

The contact and relationship between ethnic groups may feature discrepancies between the declared position of the society and the actual attitudes and actions targeted at the other ethnic group. Ethnicity is constituted through mutual contact in a given social context. It is through social contacts that the image of the other ethnicity is created while one's own ethnic identity is confirmed or reformulated. The idea of the other group's specificity is then adopted and cultural stereotypes are created. ${ }^{5}$

Stereotyping of the views of the surrounding world through the perspective of one's own ethnicity helps define the surrounding world, giving it order and meaning. It can legitimize the existing order or determine the boundaries of a particular culture. A certain form of symbiosis may develop among ethnic groups. The relationship between Transylvanian Saxons and the Romanian majority shows many elements of interaction and complementarisation. Different developments can lead to the creation of mutual negative stereotypes, leading to the delineation and strengthening of one's own ethnic identity representing a weapon against a negatively perceived competitor. ${ }^{6}$

In the case of Transylvanian Saxons and their current situation, one can speak of interethnic symbiosis with the majority Romanian population. Evidence of interethnic adaptation and complementarisation can be seen in the German minority's schools, where the overwhelming majority of pupils are Romanian. Romanian children take active part in Saxon festivals dancing in Saxon costumes. German minority politicians, especially the Transylvanian Saxons, are predominantly voted for by the majority Romanian population. The interaction is also apparent in other spheres of social life. Complementarity implies recognition of each other's differences. A shared language is a prerequisite for two-sided contact. Surrounded by majority Romanians, Transylvanian Saxons only use Romanian language in the public sphere. Ethnicity requires that a common area of the interethnic discourse and interaction be determined. ${ }^{7}$

ERIKSEN, T. H. (2012): Etnicita a nacionalismus. Antropologické perspektivy. Praha: Slon, p. 37. Ibid, p. 43.

Ibid, p. 58

lbid. 
Suppression of one's own ethnic identity and full adoption of symbols of the dominant culture and its language leads to weakening of the ethnicity and assimilation tendencies. One can talk about stigmatized identity where characteristics of one's own groups are deliberately suppressed. However, it should be noted that ethnic identity is of a fluid and relative nature. An individual can adopt multiple identities that are reflected in everyday interactions. Ethnicity may also be manipulated by its leaders. Ethnic networks can be used for political purposes to gain power, contacts and information. German schools in Transylvania are perceived as stepping stones to gain necessary information to start a career in Germany and facilitate the adaptation there. Ethnicity provides a potential source of livelihood, friends or an opportunity to find a partner.

\section{Determining Characteristics of the Transylvanian Saxons' Ethnicity}

Every individual has a need to engage in a broader group that offers him orientation in the outside world, a sense of security and belonging. A nation or an ethnic group has the opportunity to provide awareness of the common historical roots and mutual brotherhood. It provides its members with the connection between historical memory symbolized by the mythological interpretations of history and with the current social situation in a particular territory.

In interviews on their ethnic identity and cultural differences, Transylvanian Saxons frequently point out the bond to their country (Heim), specific group history (Geschichte), evangelical belief (evangelische Kirche) and their own language (Sächsisch).When examining the Transylvanian Saxons' self-concept it is important to note that in addition to addressing the issues of cultural otherness or one's own social specifics the confirmation of one's own existence is a vital aspect.

The decision whether my existence is concerned in a given case is conditioned by a standard determined by the culture and passed on as a tradition. For individuals as well as for groups, this standard prestructures the answer to the question of who they are and where they belong. The concept of identity in a given culture can be regarded as an independent item within the culture's structure. Identity as a culturally determined construct is then powered by other jointly shared cultural values, which are either found in everyday life, or are newly created.In both cases, they may receive a status symbol. ${ }^{8}$

BITTNEROVÁ, D. - MORAVCOVÁ, M. et al. (2005): Kdo jsem a kam patrím? Identita národnostních menšin a etnických komunit na území České republiky. Praha: Sofis, p. 8. 
TOMÁŠ DRS

Current Manifestations of the Ethnic Identity of Transylvanian Saxons

Ethnic identity gives an answer to the question "Who am I and where do I belong?" It raises awareness of belonging to a group and helps identify the boundaries between our people and the others. Identity can be defined as either declared or lived. Declared identity highlights the actual and symbolic acts and deliberately builds and confirms its own identity. Various identity characters can be declared or relativized. It is also possible to grade them on value scales to ascertain the importance and significance of these signs. It is also possible to talk about the so-called ethnic image, where a created impression or stylization may emphasize the identity. Another option is assimilation with the majority and blending in with the crowd. ${ }^{9}$

Lived identity represents the confirmation of one's own otherness through daily interaction. Otherness can be variously interpreted and experienced. One can talk about felt and unconscious or undeclared difference. Awareness of one's own otherness may also prove conflicting as it, in addition to confirming one's own identity, creates barriers and complicates the access to different individuals or ethnic environments. ${ }^{10}$

Examination of the ethnic classification of Transylvanian Saxons is faced with a problem of the determination of their nationality. Transylvanian Saxons are not identified strictly nationally. On a scale where Romanian stands for 1 and German is 10, the Transylvanian Saxons tend to identify themselves with German nationality. The average value on the scale is about 9.At the same time, Transylvanian Saxons add that they find the presented range and polarity inconvenient. They do not feel like political members of the German nation and clearly declare their own difference from Germanness. They highlight their unique historical story, relationship to their area and their home in Transylvania. Their collective self-concept is primarily determined regionally and historically. ${ }^{11}$

On the issue of their Germanness, Transylvanian Saxons add that they are of German origin (Abstammung), but are not Germans. A foremost Saxon intellectual and theologian Paul Philippi said:

"We are not Germans. We are merely of German origin. We participate in German culture, but politically we are a different nation. Historical developments leading to the identification of Transylvanian Saxons with the German nation was bad and wrong.

11 The questionnaire research on the ethnic identity took place in July and August 2011. In the historic Saxon villages of Biertan, Richis, Mălâncrav, Nou Sasesc or in the urban environment of Sibiu or Mediaş, all within the area called Altland, respondents answered questions about their ethnic identity in semi-structured interviews between 2013 and 2015 as well. 
Highlighting the German element in our history was to represent the opposition to Hungarization and later Romanisation of Transylvanian Saxons. Culturally, it was good, but not politically. ${ }^{12}$

The fluid nature of ethnic identity is illustrated by the fact that some Transylvanian Saxons declare their Germanness during the interviews, but in everyday life under the influence of mainstream society they clearly identify themselves with the Romanian culture. Also, identification can be found with the term Romanian German, which is common to all German-language groups in Romania when negotiating their minority positions with the government. ${ }^{13}$

In the questionnaire survey examining the signs differentiating the Transylvanian Saxons' ethnicity and their self-concept, Saxons proposed several distinguishing concepts they find to be representing of their differences from the majority population and defining their ethnic character. The most commonly used terms include traditions, customs and manners, language, culture, lifestyle. Less frequent terms are history, organization, mentality, accuracy, faith, order, economy, food or appearance. The proposed ethnic differenentiation is primarily based on cultural differences and different lifestyles or linguistic differences.Conversely, self-concept based on different group history or different religious beliefs is becoming less significant. Pluralism of ideas and characters differentiating the ethnicity shows the category of ethnic identity as a variable and fluid entity based on individualized impressions of external structures into the bodies and

12 Interview with a theologian, university professor and politician was held in Sibiu on 12 August 2013.Paul Philippi is one of the most prominent figures of Transylvanian Saxons of the late 20th and early 21st century. Born on November 21, 1923 in Brasov (Kronstadt), he actively participated in the German invasion of the Soviet Union as part of the Nazi SS squads during the Second World War. He later fell into American captivity and lived to see the end of the war in Germany. Between 1940s and late 1970s he lived mostly in Germany. After studying theology in Erlangen he lectured at the University of Heidelberg. Following the late 1970s and early 1980s, he worked at the University of Sibiu (Hermanstadt).Previously, in order to be returned Romanian citizenship he had to prove he did had not served in the German army as a volunteer. At the end of 1989 he was one of the founders of the Forum of Romanian Germans - Demokratische Forum der Deutschen in Rumänien (DFDR).From 1992 to 1998 he was the DFDR chairman. Since 1998, he has been DFDR honorary chairman. He has also been awarded a wide range of honours.

C.f. https://ro.wikipedia.org/wiki/Paul_Philippi; orhttps://de.wikipedia.org/wiki/Paul_Philippi.

13 Term pointed out by Saxon politician Hans Klein of the forum of Romanian Germans DFDR. C.f. interview with Hans Klein, male, 73 years, Sibiu, 13 August 2015.For a discussion of the concept of the Romania German based on contemporary journalism see for example. WEBER, A. (2010): Rumänien deutsche? Diskursezur Gruppenidentitäteiner Minderheit (1944-1971). Köln: Böhlau. 
personalities of the players of the game, as defined in the habitus concept of Pierre Bourdieu. ${ }^{14}$

\section{Language}

Of particular importance for the ethnic identification of an individual with a collective is language, which provides the experience of belonging to a culture. Language can be one of the defining characteristics of a nation or an ethnic group. It supplies the emotional component to an ethnic group's identification. Often, we may also talk about a language group. The boundaries between language and dialect are very shaky and blurred. According to some opinions, the concept of language is related to that of state. In accordance with this definition, a dialect would represent a language of non-state nations or ethnic minorities. ${ }^{15}$

In nations and ethnic minorities, preservation of a linguistically defined community requires unbroken intergenerational transmission of language competences, so-called language shift or exchange. Otherwise, the society is exposed to assimilation processes and decline of language awareness, which can lead to a complete loss of the language or dialect and its replacement with a more culturally aggressive language. ${ }^{16}$

The language of Transylvanian Saxons is a relic dialect colloquially denoted by the Transylvanian Saxons as "sächsisch", mainly originating from the Moselle Franconian region. It is one of the oldest still existing German dialects, originally comprising other local dialects and retaining many medieval language forms and features. These primarily include German Midwest language features with related dialects of Luxembourgish and Ripuarian. ${ }^{17}$

Centuries of contacts with Hungarians and Romanians have contaminated the Saxon dialect with elements of their languages. A strong influence can also be seen in the Reformation with the Lutheran Bible translation and codification of the new standard German, which became prevalent in correspondence of Transylvanian Saxons. Spoken

14 Questionnaire survey, July-August 2011, Altland area.

15 For the relation of language and ethnicity in the Czech Republic c.f. ŠATAVA, L. (2009): Jazyk a identita etnických menšin. Možnosti zachování a revitalizace. Praha: Slon, pp. 37-46.

16 Ibid, p. 41.

17 Literature resources on the issue of Transylvanian Saxon dialect are fairly rich. For basic understanding of the issue SEE BAIER, H., BOTTESCH, M., NOWAK, D., WIECKEN, A., ZIEGLER, W. (2011): Geschichte und Traditionen der deutschen Minderheit in Rumänien, Mediaş: Central, pp. 117-121or Internet resources:

https://de.wikipedia.org/wiki/Siebenb\%C3\%BCrger_Sachsen\#Sprache.

DOI: 10.1515/eas-2015-0016 C University of SS. Cyril and Methodius in Trnava. All rights reserved. 
communication, however, continued to be dominated by the Saxon dialect, both in rural communities and in urban centers. Until the late 1800s it was the Saxon dialect which was used for sermons in village churches. Use of the Saxon dialect was not confined to the private sphere. Although elements of the dialect differed locally, the dialect was spoken by all tiers of the Saxon society. In bourgeois circles, some ancient words were gradually replaced by standardized German terminology. Also, Austrian German from the Viennese environment had certain influence here as Transylvania was part of the Hapsburg monarchy. Currently, Saxon dialect is noticeably influenced by modern German, which is primarily due to the recent mass exodus of Saxons to Germany and the intense contacts between Saxon expatriates and Saxons who remained in Transylvania. ${ }^{18}$

Transylvanian Saxons still communicate in Saxon dialect within their community. Standard German is taught to Transylvanian Saxons at school as a foreign language and is often perceived with negative connotations, as an externally forced language. As the Saxon dialect is difficult to understand even for native Germans, Transylvanian Saxons use standard German to communicate with German visitors to Transylvania. However, the knowledge of standard German allowed them to quickly start a new life once they had arrived in Germany and made it easier for them to adapt to the new environment. ${ }^{19}$

The field research shows that when in an unmixed marriage environment, Transylvanian Saxons communicate using the Saxon dialect. Nevertheless, their communication in public and in official contacts is conducted in Romanian. The language situation in mixed marriages is complicated, with Romanian having predominant influence. Children in ethnically mixed families are bilingual, but given the sheer numerical superiority of their Romanian peers, the Romanian language culture is prevalent. The language orientation of a family is crucially determined by the mother's native language (Mutersprache).When in Germany, Transylvanian Saxons use the Saxon dialect in their families, whereas in public they only communicate in German. Saxons who remained in Romania rarely speak German, predominantly when talking to German (non-Saxon) visitors to Transylvania or tourists from other countries. ${ }^{20}$

C.f. https://de.wikipedia.org/wiki/Siebenb\%C3\%BCrger_Sachsen\#Sprache, 16th September 2015.

19 Negative attitude of Transylvanian Saxons towards German is evident from a wide range of expressions. They perceive German language as imposed in the school environment and alien: Interview with a respondent, O. W., male, 61 years, Biertan, 29th July 2014.

20 The issue of intergenerational transmission in ethnically mixed families is dealt with in DRS, T. (2015): Generational issue for minority Transylvanian Saxons in Romania. In. BITTNEROVÁ, D. MORAVCOVÁ, M. (eds): Etnické komunity 11. Praha: Faculty of Humanities (in press). 
TOMÁŠ DRS

Current Manifestations of the Ethnic Identity of Transylvanian Saxons

The questionnaire survey included a question: What kind of language do you use in everyday life? The respondents were offered a scale of 1-10 (where 1 was German only and 10 Romanian only).

The resulting value of 6 indicates that the Transylvanian Saxons tend to prefer Romanian in everyday life. However, it must be noted that the result is affected by various factors. It is obvious that in the rural communities with less than $1 \%$ of the Transylvanian Saxons in the population, no other language than Romanian can be used in the public sphere. On the other hand, it is also possible to find a municipality where a larger percentage of Saxons remained with remnants of traditional communal life tied to the local church and the local government. The local Saxons still indicate the Saxon dialect (NouSasesc) to be their dominant language. The result is also influenced by whether the village is frequently visited by Saxons from Germany both for short and long terms (Mălâncrav). At Christmas or during the summer holidays, one hears the Saxon dialect in these villages much more often than in those where the Saxon community has completely collapsed and houses have been sold (Copsa Mare, Richis) and thus there is nowhere to return and none to come back to. Many emigrants point to the fact that the Saxon dialect was the dominant language at the time of the emigration, but it was then replaced by German. $^{21}$

Some aspects of language issues in the Transylvanian Saxons may be attributed to "language atrophy of native speakers" where members of this group brought up in the local Saxon dialect left for Germany as part of the exodus and ceased to use their language in the new environment, with the rare exception of expatriate festivities and gatherings. Germany and other new homes of Transylvanian Saxons has also seen the weakening of the intergenerational "language shift". Second- and third-generation Transylvanian Saxons in the West only have partial command of the traditional dialect or understand it only passively. $^{22}$

Another modern trend that can be traced is the linguistic convergence of native and non-native speakers in the Transylvanian area, where many Romanians and Roma of older and middle generations from traditional Saxon villages speak German as a result of the

The questionnaire surveys were used when examining the manifestations of Saxon ethnic identity as a gateway to the issues researched. Subsequently, primarily qualitative ethnographic research methods were utilized, such as long-term observation and ethnographic interviews, which proved to be the most suitable to capture inner motivations and feelings of the respondents.

22 For the issue of language shift c.f. ŠATAVA, L. (2009): Jazyk a identita etnických menšin. Možnosti zachování a revitalizace. Prague: Slon, p. 40. 
inter-ethnic contact. The knowledge of German or Saxon dialect elements in this group dates back before the big departure of Saxons to Germany, i.e. before 1990, when the percentage of the Saxon population in these villages was still high. Saxon dialect could be heard on the streets and in school environment significantly more often than today. Many Romanians from the historic Saxon villages still like to use German and nostalgically recall the period of their youth, characterized by the coexistence with members of the Saxon society. $^{23}$

Members of the younger generation of Romanians now frequently attend German minority schools learning German to be well prepared to leave for German-speaking areas of Central and Western Europe. Conversely, being and feeling like a language minority, young Transylvanian Saxons only speak Romanian in the public sphere, sharing their personal experiences, challenges and hopes for the future with the majority Romanian society. The current openness and permeability of ethnic boundaries leads to the fusion of language competences, where the Romanians actively learn and use the German language. Conversely, Transylvanian Germans use Romanian to communicate with the outside world and within their mixed marriages. Language is seen as a phenomenon responding to social changes and new situations, tied to changes in the ethnic consciousness and self-concept. ${ }^{24}$

\section{Church}

Between 1542 -1550 Transylvanian Saxons adopted Lutheranism and established their own religious order. With few exceptions, all Transylvanian Saxons became members of their Evangelical Church. Believers elected their bishop seated in the village of Biertan for three centuries. Later in 1867 the bishop's seat moved to Sibiu. The advent of the Lutheran Reformation and the new translation of the Bible also meant codification of Lutheran German and spelling in written communication. Modern German was made superior to various Saxon dialects and contributed to greater coherence of areas inhabited by Transylvanian Saxons with the German cultural space of Central Europe. ${ }^{25}$

23 E.g. interview with a respondent, A. S., woman, 52 years, Biertan, 26th July 2011, or with a respondent L. P., man, 56 years, Copsa Mica, 15th August 2015.

24 Interview with a respondent, K. S., woman, 15 years, Mălâncrav, 29th July 2011.

25 Literature on the religious history of Transylvanian Saxons is very extensive, especially following the adoption of the Reformation in the 16th century. Accounts of the religious history are also given in all general overviews of the history of Transylvanian Saxons. Most recently, WAGNER, E. (1995): Geschichte der Siebenbürger Sachsen. München: Wort+Welt+Bild. For basic information o.f. online resources ach https://de.wikipedia.org/wiki/Siebenb\%C3\%BCrger_Sachsen\#Religion.

DOI: 10.1515/eas-2015-0016 C University of SS. Cyril and Methodius in Trnava. All rights reserved. 
The Saxon church largely determined the minority's culture. The church calendar was a basis for many customs and traditions. Church determined the social order in the Saxon villages and both community and school life and it also played a vital part as a political authority as the elected pastor had more power than the mayor or judge. When Saxon political autonomy disappeared completely in the late 1800s, the Saxon Protestant Church took over the role of a political representative of the Transylvanian Saxons, supporting the Saxon society in its struggle against Hungarization. Sermons were given in German and school classes were taught in German. The Evangelical Church of the Transylvanian Saxons became the central institution protecting Saxon group identity. This was especially true in the critical moments of Saxon modern history during the Second World War and during the communist dictatorship. ${ }^{26}$

The questionnaire survey included a question: How much importance do you attach to the Evangelical Church of the Saxons in Romania? (none-1, crucial-10). The resulting value of 8 indicates a considerable degree of importance the Evangelical Church of the Transylvanian Saxons is given. Especially for the older generation Saxons aged above 70 years, the Saxon church is still an indispensable body important for the Saxon minority's life. Religion is important to maintain the Saxon ethnic identity, which is a feature distinguishing it from other more dominant groups in Transylvania. Participation in the evangelical church services and the observations made there as well as the interviews with Saxon church leaders show that at present, this church is open to the Romanian population commonly attending services in the Saxon churches. Expressions of the group identity of the Transylvanian Saxons are open to other ethnic communities. The majority society or, at least some of its members, find Saxon culture very attractive also due to its connection with the Saxon Evangelical church. Belonging to a religious group turns out to be a negotiated and open ethnic category of changeable nature, existing within the fabric of social networks and responding to the current social situation and related to identity strategies of the social group. $^{27}$

\section{Festivities and Celebrations}

Among other things, group gets its share of ethnic identity via gatherings and personal participation in various forms of festivities. Cyclicality of festivals and rituals ensures

$27 \quad$ When visiting a Saxon protestant mass in the typical Saxon fortified churches, one can perceive the openness of the religious environment towards the Romanian majority. Such observations were made on 24th July 2011 in the Saxon protestant church in Biertan. 
intermediation and transfer of knowledge about the group's identity within a society. It is through festivals and celebrations that the society ensures the reproduction of the ethnic identity in a particular space and time. Group-shared and experienced festivities give a sense of reality and togetherness to both the individual and the collective. Festivities and celebrations supply structure and rhythm to the flow of time and establish order. ${ }^{28}$

Transylvanian Saxons hold a wide range of festivities, whether related to specific historic Saxon villages or Saxon culture as a whole. Saxon festivities are held in the homeland of Transylvania as well as among expatriates in Germany and other Western countries, with Kronenfest being one example of a traditional Saxon festivity. The modern tradition of Sachsentreffen was established under the changed circumstances in the early 1990s after the fall of communism and the so-called Auswanderungsschock. Strongly present in the Saxon environment is the diasporic tradition of expatriate Transylvanian Saxons' reunions, so-called Heimatsortgemeinschaften (HOG). Transylvanian Saxons also organize a number of other festivals. ${ }^{29}$

A unique one is called Crowns Feast (Kronenfest). Essentially, it is a celebration of rural youth celebrated as a last holiday before the start of the harvest season. In some Saxon villages it is celebrated on the Sunday before the feast of Peter and Paul (June 29), in other villages it is around the feast of St. John (June 24). ${ }^{30}$

On the day of the feast a crown of flowers and leaves is lifted and attached to the top of a trunk. In the inner space of the crown is a basket with a cake, a bottle of wine and sweets inside. In the early afternoon, boys and girls march through the village to the sound of brass band music. When the procession arrives under the tree, a circle is created and a pre-selected boy climbs to the crown to give a speech from the top of the tree, throw sweets to the children underneath and ultimately climb down with the bottle of wine and the cake. The youth assembled under the tree then go on to sing folk songs and dance, moving to the

ASSMANN, J. (2001): Kultura a pamět'. Písmo, vzpomínka a politická identita v rozvinutých kulturách starověku. Praha: Prostor, pp. $54-55$.

29 For traditions and customs c.f. SCOLA, O. - ACKER-SUTTER R. (1994): Dorfleben der Siebenbürger Sachsen. Tradition und Brauchtum. München: Callwey Georg; for a summary description of the traditional Saxon culture see: MYSS, W. (1993): Lexikon der Siebenbürger Sachsen: Geschichte, Kultur, Wissenschaft, Wirtschaft, Lebensraum Siebenbürgen, Köln: Wort und Welt Verlag.

30 C.f. BAIER, H., BOTTESCH, M., NOWAK, D., WIECKEN, A., ZIEGLER, W. (2011): Geschichte und Traditionen der deutschen Minderheit in Rumänien, Mediaş: Central, p. 126. 
community centre in the evening. Kronenfest is remembered by many Transylvanian Saxons as being the most important festival in Saxon calendar before the big exodus. ${ }^{31}$

A completely different type of festival is the so-called Sachsentreffen, which is organized on the third Sunday in September by the Romanian Germans' forum DFDR. Sachsentreffen is a festival dating back to 1991, shortly after the so-called Auswanderungsschock when there was a need to bring the expatriate Transylvanian Saxons together with those who remained in Transylvania. Biertan was the traditional venue to host the event, yet the festival also took place in Sibiu (2007), Bistrita (2010) and most recently in Mediaş (2015). Its external features include performances of folk dance groups, costume parades and concerts of brass music bands. The celebration begins with a festive worship accompanied by speeches by leading Saxon personalities who reflect on the current situation and the future of the Transylvanian Saxons' culture. A Honter Medal is awarded for meritorious conduct in favour of the Saxon society. Sachsentreffen is meant to reinforce the group identity of the Transylvanian Saxons and raise questions as to its new definition and place in 21 st century Transylvania. ${ }^{32}$

Expatriate Saxons in the West commemorate their homeland village communities in the so-called Heimatsortgemeinschaften. During these gatherings, popularly known as $H O G$, expatriate Transylvanian Saxons, former neighbours from their home villages in Transylvania, meet at a particular place in Germany to share memories of their former community life. They continue to cultivate mutual contacts and seek to promote their former homes through donations or remittances. They also assist with the integration of newcomers, collect voluntary contributions or document traditional life in Transylvania. Among other things, they publish so-called Heimatsbücher. Performances by folklore dance groups (Tanzgruppen) in Saxon costumes can be seen here as well. ${ }^{33}$

One of the characteristic features of the contemporary Saxon culture and its public expression is its attraction for the majority Romanian and Roma society. The current openness of the Saxon community, which has no precedent in history, leads to the fact that the majority of the performers in the Saxon dance groups are of Romanian origin. The importance of cultivating the folklore activities is disputed by Saxon elites. Some consider them to be important for young people's identification with the historic Saxon culture and emphasize their unique importance. Others consider them a historical relic emptied of any

E.g. interview with a respondent, D. S., male, 44 years, Richis, 26th July 2011.

C.f. http://siebenbuergenforum.ro/sachsentreffen/, 12th October 2015.

For the HOG festival see http://www.siebenbuerger-sachsen-hog.de/ziele/, 27th October 2015. 
spiritual content. The current form, meaning and role of Saxon festivities is largely affected by the new form of existence of this group within the transnational area where modernization changes elicit demand for new types of socially shared festivities. Traditional forms of celebrations recede into the background as they fail to meet the current needs. Their contents and meanings are criticized as dysfunctional and inconclusive. In this spirit, festivity expresses its link to the fluid nature of the ethnic identity and social needs of declaring and demonstrating social attitudes and ambitions. ${ }^{34}$

\section{Erbe und Zukunft Speech by Paul Philippi}

During Sachsentreffen, a gathering of Transylvanian Saxons, held on 17th September 2007 in Sibiu (Hermanstadt), a respectable Saxon theologian and politician Paul Philippi rendered a critical speech entitled Erbe und Zukunft, in which he attempted to formulate current problems of this group and outline directions for further efforts.

The main topic of the speech was the care of the spiritual heritage of the Saxons and linking the historical legacy to the future of the Saxon society. Rather than members of the German political nation, Transylvanian Saxons are the participants in German culture. They identify with the language and culture of the German space, with important figures of German language. The German element, however, has represented a considerable risk in modern times. The combination of heritage and Germanness has lead Transylvanian Saxons to Germany, out of Transylvania and to the brink of extinction. Modern political nationalism has proven devastating for many traditional ethnic groups. The narrowly conceived political definition of the German nation has also affected Transylvanian Saxons with their regional particularities and different historical development. ${ }^{35}$

Philippi is very critical of the current state of Saxon society. According to him, Transylvania must not become a haven for retired Germans or a short-trip destination for the expats (Heimatstouristen). He contrasts his childhood times, when Saxons, on the basis of their inherited self-government powers, participated in European politics as part of the Romanian state, and today with only folk dances and costume performances left. In the

Paul Philippi is the leading critic of the superficial presentation of traditional Saxon activities and cultural manifestations. In addition to the above speech, criticism was also voiced in a cited 2013 interview: An interview with a respondent, P. P., man, 90 years, Sibiu, 12th August 2013. PHILIPPI, P. (2010):Weder Erbenoch Zukunft?. Sibiu: Honterus, p. 241.Other works by the same author on the issue of direction and nature of the Transylvanian Saxons include PHILLIPPI, P. (1969): Die Siebenbürger Sachsen - Wer Sie Sind Und Was sie Wollen. Köln: Böhlau or PHILIPPI, P. (2007): Land des Segens?: Fragen an die Geschichte Siebenbürgens und seiner Sachsen. Köln: Böhlau.

DOI: 10.1515/eas-2015-0016 C University of SS. Cyril and Methodius in Trnava. All rights reserved. 
Saxon history, dance costumes were never meant for the stage and photographers. Paul Philippi thinks of folk dances and costumes as mere modern constructs meant to secure the future for the Saxon culture. They are false external signs devoid of any spiritual and viable legacy. As he argues, this cannot be the base to build the future of the Transylvanian Saxons' culture. ${ }^{36}$

The substance of the Saxon heritage and the main task is to preserve the traditions of the Saxon community life with self-governing political background. It is the spirit of belonging to a specific ethnic group and specific form of living in favour of the group idea that are to ensure the future. These elements used to be typical of the traditional Saxon culture in the past, allowing it to survive among the majority Romanian and Hungarian populations.

It is about this spirit of belonging and of present and future forms of life that we must think together, if we seek to link the heritage with the future. ${ }^{37}$

In addition to dance performances and festivals in costumes, Paul Philippi finds it important that political responsibility, which used to be typical of the traditional selfgoverning life, should be assumed, which has not been the case for modern generations. Traditional elements of the Saxon culture must be rediscovered and reconsidered by the present generation and passed on to the successors. Linking of the Saxon cultural heritage to the future of this group will boost its self-confidence and promote plurality of the Transylvania region. ${ }^{38}$

The analysed speech criticizes the external manifestations of ethnic strategies of identity, which it considers artificial and unsubstantial. The author is aware of the need for redefinition of the Saxon culture and its self-identification characters. He emphasises the linking of historically significant elements of the Saxon culture and its self-concept with the needs of the society in the new stage of its modern existence within the transnational space. It is questionable whether the emphasis on community and shared mentality elements will prove to be sufficiently strong concepts for further transformation of the ethnic identity of Transylvanian Saxons strongly in today's individualized in a liberalized world.

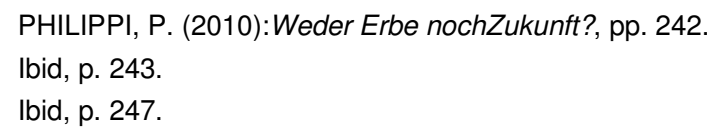

DOI: 10.1515/eas-2015-0016 C University of SS. Cyril and Methodius in Trnava. All rights reserved. 


\section{Conclusion}

In the late 1900s, the ethnic group of Transylvanian Saxons was exposed to strong migratory influences, which meant a considerable reduction of the group leading it to the brink of extinction. The population decline of Transylvanian Saxons in Transylvania became stabilized around 2000. Currently, there is no short-term threat of extinction of Transylvanian Saxons. New circumstances, however, bring about the need to provide the historically important and respected, yet very weakened, ethnic group with a place and to redefine its role in the transnational mode of existence. Saxon politicians and intellectuals are faced with the task of reformulating the group's goals and identity strategy. Defence mechanisms against the assimilation tendencies are mainly supplied by their ethnic identity. Transylvanian Saxons have traditionally defined themselves historically, linguistically, religiously, culturally and geographically. Tense political nationalism of the past two centuries has threatened their autonomy mainly through the attractiveness of German political nationalism which has led the majority of the group out of their home area in Transylvania to the German territory.

Aware of the sparsity of its population, the traditionally closed society of Transylvanian Saxons is currently opening towards the Romanian majority society. NonSaxon majority society finds the expressions of the Saxon ethnic identity attractive and trendy. The previously exclusively Saxon protestant church in Transylvania has been accepting young Romanians, Romanian teachers are teaching at German minority schools. These reputable schools are dominated by Romanian pupils for whom the knowledge of the German language is a stepping stone for their intended emigration to the German language area and easier adaptation once there. 98\% of the electorate of DFDR, the political formation of Romanian Germans successful mainly in Transylvania, is made up by Romanian voters. The Saxon folk dance groups feature young Romanians and Roma.

For many members of the Saxon elites the biggest problem, apart from the economic attractiveness of Germany, is the change of the group's mentality. Disintegration of traditional forms of the Saxon community, such as of the phenomenon of neighbourly responsibility (Nachbarschaft) in favour of modern individualism has brought about the demise of the traditional Saxon sense of self and of the Transylvanian Saxons' identification with their traditional culture as a whole. Another problem is the breaking of ties between the Saxons and their Transylvanian home. In view of these phenomena, 
resulting in the loss of confidence associated with the enormous population decline, the Saxons are setting out a short-term goal: "To make my country feel like home again." 39

The ethnic identity of the Transylvanian Saxons and its manifestations exhibit considerable stability and attractiveness for the non-Saxon majority population. Arguably, the forms and manifestations of the traditional Saxon culture are currently filled with new non-Saxon content. This trend is approved by many Saxon politicians and intellectuals who see it as their main task to create conditions for the admission of new members to the Saxon community and to show the Saxon identity, which is closely tied to Transylvania, as appealing and attractive to newcomers, both from the Romanian majority society and from the German-speaking area abroad. It is in this spirit that new ethnic identity of the Transylvanian Saxons' culture is to be created. ${ }^{40}$

The field research implies that the fluid nature of the ethnic identity, which is negotiated in everyday interactions, sets new boundaries and relationships with the majority. There are many discrepancies among the Transylvanian Saxons' statements as to whether the Saxon culture still exists or what it is distinguished by. One side is of the opinion that a there are no Saxons or their culture to speak about, merely because they are non-existent. The opposite side argues that the position of the Saxons has not changed in recent decades. Between these two extremes cautious opinions can be heard on new forms of the Saxon culture, uncertain prospects for the future and the need for modern definition of the Saxon society in the transnational mode of existence.

\section{Works cited}

ASSMANN, J. (2001): Kultura a pamět'. Písmo, vzpomínka a politická identita $\checkmark$ rozvinutých kulturách starověku. Praha: Prostor.

BAIER, H., BOTTESCH, M., NOWAK, D., WIECKEN, A., ZIEGLER, W. (2011): Geschichte und Traditionen der deutschen Minderheit in Rumänien, Mediaş: Central.

BITTNEROVÁ, D. - MORAVCOVÁ, M. a kol. (2005): Kdo jsem a kam patř́m? Identita národnostních menšin a etnických komunit na území České republiky, Praha: Sofis.

BOURDIEU, P. (1998): Teorie jednání. Praha: Karolinum. 
DRS, T. (2015): Generační otázka u národnostní menšiny sedmihradských Sasů v Rumunsku. In. Bittnerová, D. - Moravcová, M. (eds): Etnické komunity11. Praha: Fakulta humanitních studií.

DRS, T. (2015): Migrace sedmihradských Sasů. In. Bittnerová, D. - Moravcová, M. (eds): Etnické komunity - Balkánské cesty. Jihovýchodní Evropa v interdisciplinární perspektivě. Jihovýchodní Evropa v prožité minulosti a nadějích budoucnosti. Praha: Fakulta humanitních studií.

ERIKSEN, T. H. (2012): Etnicita a nacionalismus. Antropologické perspektivy. Praha: Slon.

FOUCAULT, M. (1994): Diskurs, autor, genealogie. Praha: Svoboda.

GÜNDISCH, K. (1998): Siebenbürgen und die Siebenbürger Sachsen. München: Langen-Müller .

MYSS, W. (1993): Lexikon der Siebenbürger Sachsen: Geschichte, Kultur, Wissenschaft, Wirtschaft, Lebensraum Siebenbürgen, Köln: Wort und Welt Verlag.

PHILLIPI, P. (1969): Die Siebenbürger Sachen - Wer Sie Sind Und Was sie Wollen. Köln: Böhlau.

PHILIPPI, P. (2007): Land des Segens?: Fragen an die Geschichte Siebenbürgens und seiner Sachsen. Köln: Böhlau.

PHILIPPI, P. (2010): Weder Erbe noch Zukunft?. Sibiu: Honterus.

ŠATAVA, L. (2009): Jazyk a identita etnických menšin. Možnosti zachování a revitalizace. Praha: Slon.

ŠATAVA, L. (1994): Národnostní menšiny v Evropě. Praha: Ivo Železný.

SCOLA, O. - ACKER-SUTTER R. (1994): Dorfleben der Siebenbürger Sachsen. Tradition und Brauchtum. München: Callwey Georg.

WAGNER, E. (1995): Geschichte der Siebenbürger Sachsen. München: Wort+Welt+Bild.

WEBER, A. (2010): Rumäniendeutsche?.Diskurse zur Gruppenidentität einer Minderheit (1944-1971). Köln: Böhlau.

WEITHMANN, M. (1996): Balkán. 2000 let mezi Východem a Západem. Praha: Vyšehrad.

\section{Internet resources}

https://de.wikipedia.org/wiki/ 
TOMÁŠ DRS

Current Manifestations of the Ethnic Identity of Transylvanian Saxons

https://ro.wikipedia.org/wiki/

http://siebenbuergenforum.ro/sachsentreffen/

http://www.siebenbuerger-sachsen-hog.de/ziele/ 